\title{
Teologia a czas. \\ O znaczeniu czasu we współczesnym dyskursie teologicznym i antropologicznym
}

\author{
Theology and Time. On the Importance of Time in Contemporary Theological \\ and Anthropological Discourse
}

\author{
JERZY GOCKO \\ Katolicki Uniwersytet Lubelski Jana Pawła II \\ jerzy@gocko.pl, ORCID: 0000-0002-6513-5681
}

\begin{abstract}
Streszczenie: Celem artykułu jest ukazanie czasu i temporalności człowieka jako istotnych faktorów we współczesnym dyskursie teologicznym i antropologicznym. Niemała w tym zasługa dynamicznego rozwoju eklezjologii doby Soboru Watykańskiego II, a zwłaszcza wypracowania wizji Kościoła jako wspólnoty zbawienia, który nie urzeczywistnia się gdzieś na obrzeżach historii świata i ludzkości czy poza nią. Studium ukazuje złożony proces uhistorycznienia teologii, przywołuje wielkich teologów, którzy mieli w nim znaczny udział, a także zwraca uwagę na historyczny sposób argumentowania we współczesnych debatach teologicznych.
\end{abstract}

Słowa kluczowe: czas, historia, teologia, teologia historii, Sobór Watykański II

Abstract: The aim of the article is to present time and the temporality of man as important factors within contemporary theological and anthropological discourse. This is largely due to the dynamic development of ecclesiology during the Second Vatican Council, and especially to the development of the vision of the Church as a community of salvation, which does not materialize somewhere on the fringes of the history of the world and humanity, or beyond. The study reveals the complex process of historicizing theology, recalls the great theologians who have played a significant part in it, and draws attention to the historical way of arguing in contemporary theological debates.

Keywords: time, history, theology, historical theology, Second Vatican Council

Czas jako wymiar istnienia zawsze był rzeczywistością, która fascynowała człowieka i naukę. Jednak wydaje się, że dopiero dwa ostatnie wieki wniosły w te poszukiwania najwięcej przemyśleń, wobec których współczesna teologia nie może przejść obojętnie $^{1}$. Doprowadziło to do odkrycia myślenia historycznego, a wraz z nim historycznego charakteru samej myśli i rozumienia. Do czasów nowożytnych bowiem (a zwłaszcza w starożytności i w średniowieczu) cały fenomen poznania uważano na ogół za ahistoryczny, bezczasowy i bezprzestrzenny, na podobieństwo duszy lub ducha.

1 Liszka, Wpływ nauki o czasie, 14-21. 
Ścisły związek między myślą a historią zaczęto stopniowo dostrzegać dopiero od Odrodzenia, a zwłaszcza od romantyzmu. Choć główne nurty refleksji nad czasem wywodziły się raczej z obszaru filozofii (np. filozofia egzystencjalna) ${ }^{2}$ i nauk empirycznych (np. prace Alberta Einsteina), to jednak proces ten nie ominął także teologii chrześcijańskiej. Kiedy to do wielu dyscyplin teologicznych zaczęła przenikać myśl historyczna i doszło do oryginalnego związania myślenia historycznego z teologicznym, do prac przedstawicieli innych dziedzin bardzo szybko dołączyły prace teologów ${ }^{3}$.

Uzmysłowiły one z całą mocą, że człowiek jest nie tylko istotą, która żyje w określonym czasie. $\mathrm{O}$ wiele większą wymowę ma fakt, że cała rzeczywistość człowieka ma charakter czasowy; jest on istotą historyczną ze wszystkimi konsekwencjami, jakie to niesie dla jego życia. Dziś, jak podkreślał Sobór Watykański II, to doświadczenie czasu jest zauważalne ze szczególną intensywnością, ponieważ

historia przyśpiesza bieg tak gwałtownie, że jednostki z trudem mogą dotrzymać jej kroku. Los wspólnoty ludzkiej staje się wspólny i nie rozdziela się już na jak gdyby różne wątki historyczne. W ten sposób rodzaj ludzki przechodzi od statycznego poznania porządku rzeczywistości do poznania bardziej dynamicznego i ewolucyjnego, skąd wywodzi się nowy, ogromny kompleks problemów, który wymaga nowych analiz i syntez

W perspektywie chrześcijańskiej doświadczenie czasu odczytywane jest nie tylko jako jeden z podstawowych czynników warunkujących ludzkie życie, ale także jako ważny punkt odniesienia. Po pierwsze, dlatego że cała rzeczywistość zbawienia par excellence jawi się jako doświadczenie historyczne. Po wtóre, to zdeterminowanie egzystencji człowieka wierzącego przez wymiar czasowy prowadzi do określonych reperkusji w strukturze antropologicznej ludzkiego działania. Już bowiem na płaszczyźnie prawnonaturalnej należy stwierdzić, że człowiek jako podmiot moralny, dzięki czasowości swojej egzystencji, nie jest wyłączony poza historię, jego rozwój nie jest jakimś przypadkowym stawaniem się, lecz wzrastaniem w historyczności czasu i miejsca. Każdy moment historyczny przemawia do świadomości człowieka i zwraca uwagę na wielkie znaczenie całej historii.

Celem artykułu jest ukazanie czasu i temporalności człowieka jako istotnych faktorów we współczesnym dyskursie teologicznym i antropologicznym. Niemała w tym zasługa dynamicznego rozwoju eklezjologii doby Soboru Watykańskiego II, a zwłaszcza wypracowania wizji Kościoła jako wspólnoty zbawienia, który nie urzeczywistnia się gdzieś na obrzeżach historii świata i ludzkości czy poza nią; przeciw-

2 Fundamentalną pozycją dotyczącą omawianego zagadnienia jest wydane po raz pierwszy w $1927 \mathrm{r}$. w Halle dzieło Martina Heideggera Sein und Zeit.

Góźdź, Teologia człowieka, 346-348.

Sobór Watykański II, Gaudium et spes, 5. 
nie, choć w zakresie empirycznym wewnętrznie ją przekraczają, to jednak realizują się w historii, dzięki historii i z historii. Studium będzie także okazją do ukazania złożonego procesu uhistorycznienia teologii, do przywołania wielkich teologów, którzy mieli w nim znaczny udział, a także do zwrócenia uwagi na historyczny sposób argumentowania we współczesnych debatach teologicznych.

\section{Kościół i człowiek zanurzony w czasie i historii}

Myślenie historyczne $\mathrm{w}$ teologii pozostawało przez długi czas na peryferiach refleksji teologicznej. Od czasów św. Justyna, poprzez Orygenesa, cały neoplatonizm chrześcijański, następnie św. Tomasza z Akwinu i scholastykę aż do Soboru Watykańskiego II dominowała teologia oparta na założeniu, że rzeczywistość, o której traktuje - idealna, boska, wieczna i niezmienna - jest „ahistoryczna”. Konsekwencją takiego rozumienia przedmiotu teologii było przekonanie, że poznanie historyczne nie prowadzi do żadnej prawdy, a jako relatywistyczne jest zgoła antyteologiczne ${ }^{5}$. Także człowiek ujmowany był poza historią czy ponad historią, przynajmniej w sferze ducha. Historyczność w tym kontekście była uważana za coś negatywnego, za przemijanie w nicość, za degradację bytu, formę alienacji czy uprzedmiotowienia ducha, a także za relatywizm, nieokreśloność lub amorficzność. Dziś z kolei dominuje podejście pozytywne. Historię rozumie się jako kreatywną, twórczą, generatywną, personalizującą. Cały człowiek i rzeczywistość, jakiej się dotyka, jest przedmiotem i podmiotem historii, jest historią w sobie, podlega nie tylko czasowi, ale także wymiarowi przestrzeni, która jest drugą „niepomijalną” kategorią historyczności ${ }^{6}$.

Coraz bardziej umacniała się świadomość, że dzieje Kościoła jako wspólnoty zbawienia urzeczywistniają się w historii, dzięki historii i z historii, choć jednocześnie ją przekraczają. To szczególne uwyraźnienie świadomości historycznej Kościoła, której początkiem jest „wkroczenie Boga w historię”, jest - jak już wspomniano - zasługą Soboru Watykańskiego II. W „wydarzeniu soborowym”, a zwłaszcza w trzech doktrynalnych konstytucjach soboru: Dei verbum, Lumen gentium i Gaudium et spes, znalazła uwieńczenie teologia wrażliwa na ekonomię zbawienia bardziej niż na abstrakcyjne studium dogmatycznych aspektów wiary. Vaticanum II potwierdził i uprawomocnił nowy sposób uprawiania teologii, wypracowywany od początku XX wieku, zwłaszcza we Francji, który chciał potraktować z powagą wszystkie konsekwencje idei Objawienia chrześcijańskiego, rozumianego jako historia zbawienia, a nie jedynie jako katalog prawd objawionych.

Bartnik, Chrystus jako sens historii, 124; Macheta, „Teologia historyczna”, 265

Bartnik, Hermeneutyka personalistyczna, 209. 


\section{Ku myśleniu historycznemu w teologii}

Włączenie historyczności w zakres analiz teologicznych dokonywało się stopniowo; w pierwszej kolejności w obszarze teologii protestanckiej, następnie w szerszym zakresie także w teologii katolickiej. Szczególną rolę w tym zakresie odegrały obie, tj. ewangelicka i katolicka, szkoły tybińskie ${ }^{7}$. To, co dawniej dość często zaniedbywano i uważano za zaciemnienie myślenia (historyczność, doczesność, czas), pojawiło się odtąd w samym centrum myśli katolickiej. Wśród tych, którzy w szerokim stopniu przyczynili się do przezwyciężenia nieufności do historii, czasu i nauk opisowych (historycznych, społecznych czy przyrodniczych) i uwzględniania ich dorobku w hermeneutyce teologicznej, byli m.in. prekursorzy odnowy eklezjologii katolickiej doby ostatniego soboru, prowadzącej do otwarcia Kościoła na świat współczesny. Wśród nich należy wskazać zarówno na najważniejszych papieży okresu między dwoma ostatnimi soborami ekumenicznymi: Leona XIII, św. Piusa X, Piusa XI, Piusa XII i św. Jana XXIII, jak i na szereg wybitnych teologów, którzy od początku XX wieku, a nawet wcześniej, jak w przypadku Johanna Adama Möhlera z ośrodka tybińskiego, w swoich badaniach podejmowali problematykę eklezjologiczną: Romano Guardiniego, Henriego de Lubaca, Marie-Dominique’a Chenu, Yvesa Congara, Charlesa Joumeta, Karla Rahnera, Hansa Ursa von Balthasara i Jeana Danielou'. Z perspektywy czasu widać dobrze, że odkrycie myślenia historycznego stało się przełomem, który swoimi konsekwencjami dotknął także współczesną myśl teologiczną, czego przejawem jest rozwój i nowe sposoby uprawiania teologii katolickiej po Soborze Watykański II.

Coraz bardziej dochodziły do głosu poglądy, że teologia chrześcijańska jest nauką nie o ideach i abstrakcjach, lecz o konkretnych bytach i sytuacjach; nie tyle o samym Bogu, ile raczej o człowieku w relacji do Boga, nie o świecie „niezmiennym", lecz poddanym historii. Stopniowe zbliżenie między myśleniem teologicznym a historycznym doprowadziło do ciekawego spotkania się historii z teologią dogmatyczną w postaci tzw. teologii historii, gdzie myślenie teologiczne zaczęło tracić dużo z tradycyjnego ahistoryzmu, a myślenie historyczne wykraczało daleko poza samo konstatowanie faktów przeszłych, stając się raczej jednym ze sposobów samopoznania się ludzkości. Przekształceniu ulegała także koncepcja przedmiotu teologii ze strukturalnej czy metafizycznej na egzystencjalną. W dalszej kolejności proces rozpoczęty przez teologię historii objął całą teologię, która swoimi zainteresowaniami zaczęła obejmować konkretną, a więc historyczną egzystencję ludzką. Nurt ten, którego głównymi przedstawicielami byli m.in. Karl Rahner, Piet Schoonenberg, Oscar Cullmann, Joseph Ratzinger, Walter Kasper i na gruncie polskiej teologii Czesław Stanisław Bartnik, swoim wpływem objął także Sobór Watykański II, gdzie

Leube, Geschichte des Tübinger Stifts; Geiselmann, Die katholische Tübinger Schule.

Gocko, Kościół obecny w świecie, 41-62. 
zasugerowano między innymi przetworzenie tradycyjnej teologii o ideach na naukę o dziejach zbawienia ${ }^{9}$.

Wyraźna asymilacja myślenia historycznego, a także niewątpliwy wpływ myśli protestanckiej doprowadziły do dynamicznego rozwoju uniwersalnej hermeneutyki katolickiej, tłumaczącej świat i człowieka przez Boga, przede wszystkim zaś przez Jezusa Chrystusa oraz Ducha Świętego. Pomijając w tym miejscu szczegółowe analizy, należy stwierdzić, że hermeneutyka ta wybrzmiewa z całą mocą w nauczaniu Soboru Watykańskiego II, który z jednej strony ją odziedziczył, z drugiej zaś ugruntował. Jest to pewien rodzaj hermeneutyki metafizycznej, według której rzeczywistość jest tłumaczona i interpretowana przez ponadrzeczywistość, człowiek - przez Boga, a czas - przez wieczność. Przy czym hermeneutyce podlega nie tylko słowo, język i mowa w ścisłym znaczeniu, ale także zdarzenia historyczne, rzeczy i czyny. W stosunku do rzeczywistości Kościoła można zauważyć w nauce soboru podejście dialektyczne, w którym Kościół traktowany jest jako naczelna zasada hermeneutyczna zarówno w aspekcie historycznym, jak i ponadhistorycznym. Funkcja historyczna uwidacznia się wtedy, gdy działa on jako kontynuacja Tradycji, a zwłaszcza jako interpretator własnej świadomości w czasie i w przestrzeni. Jest także sam w sobie głównym hermeneutą ponadhistorycznym autorytatywnie działającym w imieniu Jezusa Chrystusa, na którym spoczywa zadanie autentycznej interpretacji słowa Bożego ${ }^{10}$.

9 Sobór Watykański II, Optatam totius, 16; Macheta, „Teologa historyczna”, 264-265. Można mówić o zasadniczej różnicy w ujęciu relacji między historią zbawienia a historią świecką w ujęciu katolickim i protestanckim. Wielu teologów protestanckich (Paul Yorck von Wartenburg, Gerhard von Rad, Oscar Cullmann i in.) stało na stanowisku wyraźnie fideistycznym, zawężającym historię jako taką i samo jej pojęcie jedynie do sytuacji odpowiedniej ingerencji Boga, a zwłaszcza objawienia żydowskiego i chrześcijańskiego. W tym przypadku ci, którzy nie są ani żydami, ani chrześcijanami, mieliby nie znać historyczności w ścisłym znaczeniu. Właściwą historią jest tylko historia Jezusa Chrystusa oraz określona przezeń historia zbawienia, wszystko inne winno być odczytywane jedynie jako historia pozorna i mityczna. Stanowisko takie jest odrzucane przez teologię katolicką, podkreślającą realność historii kreacyjnej i świeckiej, dla zaistnienia i poznania której nie jest potrzebne Objawienie. Jak podkreśla Czesław Stanisław Bartnik (Hermeneutyka personalistyczna, 210-211), „jest tylko jedna i ta sama historia, która obejmuje całość ludzkiego bytu, tyle że o dwóch wektorach - doczesnym i zbawczym. Każda ma też swój trójschemat: aspekt alfalny - punkt wyjścia, aspekt centralny - głębię realności i aspekt omegalny - punkt spełnienia. Każda ma tę samą dwuwartościowość: wartość dodatnią albo ujemną, czyli naprzeciwko historii [stworzenia i zbawienia] staje - paradoksalnie w niej samej - antyhistoria [historia antystworzenia i historia antyzbawienia]".

10 Sobór Watykański II, Dei verbum, 2, 8, 10. 


\section{Historyczność jako zasada dyskursu teologicznego i jego argumentacji}

Nie można sobie dziś wyobrazić uprawiania teologii bez uznania historii, a szerzej - odniesienia do wymiaru czasowo-przestrzennego jako wewnętrznej zasady myślenia teologicznego i jednej z głównych podstaw argumentowania teologicznego. Teologia, która prowadząc człowieka na spotkanie z Bogiem, sugeruje konieczność opuszczenia terenu historii, nie jest teologią biblijną ${ }^{11}$. Odwoływanie się do argumentacji historycznej w teologii ma na celu nie tyle dostarczenie tzw. dowodu historycznego w argumencie z Tradycji (tak więc nie chodzi tu o historię teologii czy historię doktryn i dyscyplin teologicznych), ile raczej nawiązanie do pierwotypu metodologii teologicznej występującego pod postacią loci theologici, a więc obszarów, z których wyrasta i w których tkwią dane istotne dla poznania teologicznego ${ }^{12}$. Warto w tym miejscu przypomnieć, że Melchior Cano, opisując w De locis theologici (1562) dziesięć podstawowych miejsc poznania teologicznego, jako ostatnią wymienił właśnie historię, rozumianą jako dzieje człowieka ${ }^{13}$. Wydaje się, że chciał przez to niejako zwrócić uwagę współczesnym sobie przedstawicielom scholastyki, pielęgnującym teologię esencjalną, spekulatywną i dedukcyjną, na potrzebę „uwzględniania w teologii struktur czasowych, zmiennych i przemijających, nie tylko jako kontekstu dociekań, lecz także jako pełnoprawnego źródła teologicznego poznania"14.

Postulat historyczności teologii sprowadza się ostatecznie do odejścia od nurtów platonizujących, które za swój przedmiot mają idee, pojęcia czy principia. W tym sensie analizują też najważniejsze kwestie teologiczne o Bogu, duszy ludzkiej, Kościele, normach moralnych i innych - zawsze jako rzeczy pozahistoryczne i pozaczasowe. Teologia ukierunkowana historycznie stara się odejść od tych abstrakcyjnych wyobrażeń czy pojęć i być nauką dotykającą konkretnych rzeczywistości. W ten sposób cała teologia ulega przeobrażeniu, stając się nauką antropologiczną, nauką o człowieku w relacji do Boga ${ }^{15}$. W świetle takiej teologii człowiek brany jest w jego konkretnej, historycznej egzystencji, łącznie z ciałem, materią, a także światem, w którym żyje, a więc historią, kulturą i całym wymiarem społecznym. Tak więc pierwszorzędnym przedmiotem i źródłem tej teologii nie są teksty, zdania czy idee, lecz realnie dokonujące się zbawcze spotkanie człowieka i ludzkości z Bogiem na bazie egzystencji dziejącej się w świecie historii. Teologia po zwrocie antropologicznym w swoim przedmiocie nie wstrzymuje się przed objęciem refleksją także obsza-

11 „On ne quitte pas le terrain de l'histoire dans l'illusion d'entrer ainsi en contact avec Dieu” (Xhaufflaire, Théologie politique, 40).

Szymik, „Loci theologici”, 757-761; Seckler, „Die ekklesiologische Bedeutung”, 37-65

Cano, O źródłach teologii, 27.

Rabczyński, „Historia sacra a historia profana”, 123.

Bartnik, Chrystus jako sens historii, 124-126. 
rów „świeckich”, czego przejawem jest tzw. teologia rzeczywistości ziemskich oraz różnego rodzaju teologie dopełniaczowe (Genetiv-Theologie). Jeśli w obszarach tych daje się uchwycić jakieś znaki Bożej ingerencji (stworzenie, Wcielenie, Odkupienie itp.), wtedy to pasmo ingerencji ujmuje się jako realizację zbawienia i w refleksji naukowej przyjmuje ono nazwę teologii historiozbawczej lub teologii historii zbawienia ${ }^{16}$. Trzeba jednak pamiętać, że w świetle Objawienia chrześcijańskiego odniesienie do historii zbawienia nie oznacza jakiegoś skoncentrowania na wydarzeniach historycznych o charakterze bezosobowym. Dzieje zbawienia w ujęciu biblijnym są zawsze dziejami międzyosobowych relacji Boga z człowiekiem (z ludźmi) także poprzez wydarzenia historyczne ${ }^{17}$.

W ciągu dziejów najradykalniejszą formą nachylenia się Boga ku człowiekowi, a zarazem centralnym wydarzeniem w teologii historii jest Wcielenie Syna Bożego. Wtedy to Słowo Boże przyjęło konkretną ludzką naturę, ludzki czas i ludzkie dzieje. Przyjęcie ludzkiej natury stało się także przyjęciem ludzkiej historii ${ }^{18}$. To właśnie poprzez Wcielenie historia weszła do integralnego pojęcia ludzkiej natury Chrystusa. A odkąd Odwieczny Logos stał się postacią umiejscowioną w czasie, sama historia przybrała określony sens, stała się procesem celowym ${ }^{19}$.

\section{4. Życie moralne chrześcijanina między „już” a „jeszcze nie”}

Karl Rahner, określając podmiotowość osoby, zwrócił uwagę na historyczność, światowość oraz czasowość człowieka. Jest on istotą, której subiektywność i wolna osobowa interpretacja realizują się przez świat, czas i historię. Miejscem urzeczywistniania się transcendentalności i wolności jest historia ${ }^{20}$. W tej perspektywie formę teologii zbawienia, czyli teologii o konkretnej, żyjącej w czasie i przestrzeni egzystencji ludzkiej w relacji do chrześcijańskiego zbawienia, może otrzymać nie tylko teologia dogmatyczna, ale także inne działy refleksji teologicznej ${ }^{21}$. Fakt, że egzystencja człowieka jest egzystencją zdeterminowaną przez wymiar czasowy, ma ważne konsekwencje przede wszystkim dla moralności chrześcijańskiej. Uwzględnienie kategorii czasu,

16 Postulat uprawiania historiozbawczej teologii realizuje znany podręcznik dogmatyki Mysterium Salutis. Z kolei na gruncie polskiej teologii problematykę tę podejmuje w licznych publikacjach Czesław Stanisław Bartnik (Historia ludzka i Chrystus; Chrystus jako sens historii; Historia i myśl; Teologia historii; Osoba i historia; Eseje o historii zbawienia).

17 Nagórny, „Rola wiodących idei biblijnych”, 289.

18 Rahner, Podstawowy wykład wiary, 121-122.

19 Rabczyński, „Historia sacra a historia profana”, 127-129.

20 Rahner, Podstawowy wykład wiary, 39.

21 Taką interpretację potwierdza tekst soborowy, wzywający wszystkie dyscypliny teologiczne, by ich odnowa dokonała się "dzięki żywszemu powiązaniu $i$ misterium Chrystusa i historią zbawienia” (Sobór Watykański II, Optatam totius, 16). 
a zwłaszcza historyczności, oraz wybranie innej podstawy dociekań i innej metodologii niż tradycyjne ujęcia w teologii moralnej sprawiły, że zaczęła ona stopniowo przybierać nowe cechy, różne od przymiotów, które dotychczas posiadała. Stało się to również okazją do ważnych dysput w obszarze katolickiej teologii moralnej, których rezultatem były nowe ujęcia wielu ważnych kwestii, m.in. dotyczących historyczności norm moralnych oraz nowych koncepcji w określeniu i hermeneutyce prawa naturalnego. W ukazaniu najważniejszych przymiotów posoborowej teologii moralnej mówi się wprost o rysie kairologicznym, antropologicznym czy eschatologicznym, które bezpośrednio odwołują się do refleksji nad sensem dziejów, problemem czasu i przemijalności ludzkiej egzystencji w historii ${ }^{22}$. Powyższe kwestie, pomimo ich doniosłości, nie są jednak celem niniejszych rozważań.

Człowiek jako podmiot moralny, dzięki czasowości swojej egzystencji, nie jest wyłączony poza historię. Jego rozwój nie jest nigdy jakimś nagłym i niespodziewanym stawaniem się, lecz wzrastaniem w historyczności czasu i miejsca. Każdy moment historyczny przemawia do świadomości człowieka i zwraca uwagę na wielkie znaczenie całej historii ${ }^{23}$. Egzystencja chrześcijanina staje się egzystencją między „już" a ,jeszcze nie" ${ }^{24}$, między zbawieniem dokonanym a tym, które ma się jeszcze spełnić. Przyjmuje formę pielgrzymowania, które nadaje względny charakter wszystkim wartościom doczesnym. To jednak nie zwalnia go od obowiązku szukania zrozumienia czasu, który jest mu dany, przyszłości, w której spełnia się jego los, a także los Kościoła ${ }^{25}$.

Rozwój teologii historycznej lub historiozbawczej, której przedmiotem są dzieje zbawienia, interpretowany jako realizacja soborowego postulatu podniesienia rangi myślenia historycznego, jest niewątpliwie zjawiskiem zadziwiającym i spektakularnym, bowiem jeszcze do niedawna w teologii przeważała opinia, że historia i $z b a-$ wienie były całkowicie odrębnymi, a niekiedy wręcz przeciwstawnymi rzeczywistościami. Historia miałaby być następstwem grzechu pierworodnego, materializacją ducha, bezsensownym przemijaniem, degradacją bytu; z kolei zbawienie miałoby mieć jedynie aspekt absolutny, niezmienny, boski, statyczny, niebiański, niestyczny

22 Greniuk, Katolicka teologia moralna, 174-175; Fuchs, Ricercando la verità morale (zwłaszcza rozdz. V: „Storicità e norma morale", 80-101).

23 Warto w tym miejscu przywołać rozumowanie Wolfharta Pannenberga, który chce związać każde wydarzenie z perspektywą całych dziejów, łącznie z ich eschatologią. Dla niego dzieje są procesem łączenia pojedynczych wydarzeń z całością dziejącej się rzeczywistości. Zob. Góźdź, „Teologiczne rozumienie historii", $72-73$.

24 Interesującą krytykę wywodzącego się z teologii dialektycznej Karla Bartha sformułowania ,już i(a) jeszcze nie” przeprowadził z perspektywy logiki stosowanej Jerzy Dadaczyński („Kilka uwag o logice teologii", 37-39), który traktuje je jako przejaw antynomii we współczesnej teologii. Kwestię tę autor analizuje w szerszym kontekście adekwatności logiki klasycznej wobec pojawiających się sprzeczności we współczesnym paradygmacie teologii, na co odpowiedzią może być budowanie teologii na logikach nieklasycznych (parakonsystentnych). 
w żaden sposób ze światem doczesnym. Dopiero ostatnie dziesięciolecia przed soborem, głównie z inspiracji różnorodnych nurtów personalizmu chrześcijańskiego, poczęły kształtować pogląd przeciwny, że historia i zbawienie w aspekcie realności warunkują się wzajemnie i dopełniają, historia ludzka potrzebuje zbawienia, a realne zbawienie wymaga historii. Zbawienie $\mathrm{z}$ istoty swej jest odniesione do historii człowieka. Dlatego chrześcijaństwo i dzieje Kościoła jako główny nośnik zbawienia w świecie, nie są tylko ideą, abstrakcją, cząstką wieczności, lecz określoną egzystencją człowieka także w wymiarze wspólnoty, sposobem jego stawania się w czasie i przestrzeni, a więc w historii. Dzieje Kościoła jako wspólnoty zbawienia jawią się w historii, dzięki historii i z historii, choć ją wewnętrznie przekraczają w zakresie empirycznym. Historia potęguje możliwość obecności Boga w świecie na sposób naturalny (w odniesieniu do perspektywy stwórczej) i nadprzyrodzony (w odniesieniu do Osoby Jezusa Chrystusa). Historia zbawienia to „odsłanianie się Boga” w Jezusie Chrystusie, normowanie dziejów, określanie ich istoty i interpretowanie człowieka ${ }^{26}$.

\section{Zakończenie}

Tak wyraźne uwypuklenie znaczenia myślenia historycznego czy historycznego widzenia całej rzeczywistości, a więc także Objawienia, zbawienia, wiary, teologii i w końcu Kościoła Chrystusowego jako wspólnoty zbawienia, ma - na co wskazano w toku niniejszych badań - niezwykle istotne znaczenie dla argumentacji teologicznej i dyskursu antropologicznego w teologii. Objawienie bowiem - jako jądro historii zbawienia - nie tylko występuje w szacie historycznej, lecz jest faktem historycznym - jest stawaniem się zbawienia w czasie ${ }^{27}$. Wzajemne przenikanie się różnych porządków ontologicznych: stworzenia, Odkupienia i Zbawienia, widoczne jest także wyraźnie w samej strukturze historii zbawienia, dla której podstawą ontologiczną jest historia stworzenia (historia creationis, historia profana) oraz ekonomia stworzenia (oeconomia creationis, providentia naturalis), tworzące rodzaj przedhistorii zbawienia. Jest ona podstawą dziejów ludzkości i świata. Posiada swoją autonomię i wolność względem Kościoła, jednakże nie jest sekularystyczna, gdyż u jej podstaw i kresu jest Stwórca ${ }^{28}$. Na podstawie stworzenia rozgrywa się historia doświadczania Boga w świecie, dramat Objawienia, Odkupienia i odrodzenia tego świata przez relację Boga i człowieka (historia experientiae Dei, historia revelationis).

26 Bartnik, Historia i myśl, 111-112.

27 Bartnik, „Poznanie historyczne w teologii”, 145.

28 Sobór Watykański II, Gaudium et spes, 36, 41, 55, 71, 75. 
Spotykają się w niej dwa widoczne nurty: zstępujący od Boga ku stworzeniu drogą natury i łaski zarazem oraz wstępujący od stworzenia ku Bogu przez otwarcie. Trzecią strukturą jest zbawienie nadprzyrodzone i eschatologiczne, dziejące się nie „po historii”, ale antycypacyjnie „w historii” i polegające na spełnianiu się osoby ludzkiej przez proces pogłębiającej się komunii z wewnętrznym życiem Trójcy Świętej. Archetypem spotkania się obu nurtów w jedną najbardziej sensowną całość jest oczywiście Osoba Jezusa Chrystusa.

Widać więc, że choć zbawienie w znaczeniu finalnym oznacza absolutne spełnienie się osób ludzkich w łonie Trójcy Świętej, zapoczątkowane jest ono już na ziemi w określonych wydarzeniach oraz momentach czasoprzestrzennych. Stąd niezrozumiałe w świetle współczesnej teologii są niektóre nurty (platonizm, neoplatonizm, manicheizm) ujmujące relację zbawienia i historii na zasadzie ucieczki od świata i jego historii. Posoborowa teologia katolicka widzi te rzeczywistości jako wzajemnie się warunkujące: czas (historia) istnieje ze względu na zbawienie człowieka, a zbawienie jest możliwe tylko dzięki pozytywnej funkcji historii ${ }^{29}$.

Ujęcie teologii jako refleksji nad historią zbawienia oznacza, że nie można wypracowywać koncepcji teologicznych bez odniesienia się do współczesnego świata, aktualnych wydarzeń, bez zaangażowania w dzieje człowieka, bez obecności w jego aspiracjach i strukturach życia społecznego, które tworzy. Współczesne dzieje świata i człowieka są miejscem stałej inwencji i stałego rodzenia się teologii.

\section{Bibliografia}

Bartnik, C.S., Chrystus jako sens historii (Wrocław: Wydawnictwo Wrocławskiej Księgarni Archidiecezjalnej 1987).

Bartnik, C.S., Eseje o historii zbawienia (Lublin: Standruk 2002).

Bartnik, C.S., Hermeneutyka personalistyczna (Lublin: Katolicki Uniwersytet Lubelski - Polihymnia 1994).

Bartnik, C.S., Historia i myśl (Lublin: Pracownia Poligraficzna przy Prywatnym Katolickim Liceum Ogólnokształcącym 1995).

Bartnik, C.S., Historia ludzka i Chrystus. Szkice z chrześcijańskiej wizji dziejów (Katowice: Księgarnia Świętego Jacka 1987).

Bartnik, C.S., Osoba i historia. Szkice z filozofii historii (Lublin: Standruk 2001).

29 Problem historyczności, oprócz wskazanych pozytywnych aspektów, stał się dla teologii także poważnym wyzwaniem. Mocne akcentowanie w teologii koniunktur czasowych może budzić niepokój o relatywizowanie prawdy, dogmatów i zasad moralnych oraz zarzuty o historycyzm. Nie można zapominać, że afirmacja historyczności w teologii przypadła w czasie, gdy narastał klimat antymodernistyczny, który w nowych nurtach dostrzegał jedynie relatywizm, subiektywizm i permisywizm moralny. Z drugiej strony swoje apogeum osiągnęła ona w dobie postmoderny, która powyższymi stanowiskami opisuje i definiuje całą rzeczywistość. 
Bartnik, C.S., „Poznanie historyczne w teologii”, Roczniki Teologiczno-Kanoniczne 19/2 (1972) 145-158.

Bartnik, C.S., Teologia historii (Lublin: Standruk 1999).

Cano, M., O źródłach teologii. Według wydania: Serwacego Sassena, nakładem spadkobierców Arnolda Byrckmanna, w Lowanium 1564 roku. W oparciu o wydanie Juan Belda Plans, De locis theologicis, Biblioteca de Autores Cristianos, Madrid 2006 (tł. J. Wojtkowski) (Olsztyn: Wojtkowski 2016).

Dadaczyński, J., „Kilka uwag o logice teologii”, Zagadnienia Filozoficzne w Nauce 57 (2014) 33-58 [Numer specjalny: nauka i religia].

Feiner, J. et al. (red.) Mysterium Salutis. Grundriß heilsgeschichtlicher Dogmatik (Einsiedeln Zurich - Köln: Benziger 1965-1976) I-V.

Fuchs, J., Ricercando la verità morale (Teologia morale. Studi e testi 6; Cinisello Balsamo: San Paolo 1996).

Geiselmann, J.R., Die katholische Tübinger Schule. Ihre theologische eigenart (Freiburg - Basel Wien: Herder 1964).

Gocko, J., Kościół obecny w świecie - posłany do świata. Teologiczno-społeczne aspekty posłannictwa Kościoła w świecie po Soborze Watykańskim II (Lublin: Wydawnictwo KUL 2003).

Góźdź, K., Teologia człowieka. Z najnowszej antropologii niemieckiej (Lublin: Wydawnictwo KUL 2006).

Góźdź, K., „Teologiczne rozumienie historii u Wolfharta Pannenberga”, Collectanea Theologica 54/4 (1984) 69-82.

Greniuk, F., Katolicka teologia moralna w poszukiwaniu własnej tożsamości (Lublin: RW KUL 1993).

Heidegger, M., Sein und Zeit (Halle: Niemeyer 1927).

Leube, M., Das Tübinger Stift 1770-1950. Geschichte des Tübinger Stifts (Stuttgart: Steinkopf 1954).

Liszka, P., Wpływ nauki o czasie na refleksję teologiczną (Warszawa: Palabra 1992).

Macheta, K., „Teologia historyczna”, Historia i Logos (red. K. Macheta - K. Góźdź - M. Kowalczyk) (Lublin: Katolicki Uniwersytet Lubelski 1991) 264-278.

Nagórny, J., „Rola wiodących idei biblijnych w teologii moralnej”, Veritatem facientes. Ksiega Pamiątkowa ku czci Księdza Profesora Franciszka Greniuka (red. J. Nagórny - J. Wróbel) (Lublin: RW KUL 1997) 259-292.

Nagórny, J., Teologiczna interpretacja moralności Nowego Przymierza (Lublin: RW KUL 1989).

Rabczyński, P., „Historia sacra a historia profana. Szkic z teologii historii”, Forum Teologiczne 18 (2017) 123-134.

Rahner, K., Podstawowy wykład wiary. Wprowadzenie do pojęcia chrześcijaństwa (tł. T. Mieszkowski) (Warszawa: Pax 1987).

Seckler, M., „Die ekklesiologische Bedeutung des Systems der 'loci theologici'. Erkenntnistheoretische Katholizität und strukturale Weisheit", Weisheit Gottes - Weisheit der Welt. Festschrift für Joseph Kardinal Ratzinger zum 60. Geburtstag (red. W. Baier - S.O. Horn V. Pfnürr) (Sankt Ottilien: EOS 1987) I, 37-65.

Sobór Watykański II, Dekret o formacji kapłańskiej „Optatam totius” (1965).

Sobór Watykański II, Konstytucja dogmatyczna o Objawieniu Bożym „Dei verbum” (1965). 


\section{JERZY GOCKO}

Sobór Watykański II, Konstytucja duszpasterska o Kościele w świecie współczesnym „Gaudium et spes" (1965).

Szymik, J., „Loci theologici”, Leksykon teologii fundamentalnej (red. M. Rusecki et al.) (Lublin Kraków: Wydawnictwo „M” 2002) 757-761.

Xhaufflaire, M., La théologie politique. Introduction à la théologie politique de Jean-Baptiste Metz (Cogitatio fidei 69, Paris: Cerf 1972) I. 